\title{
REFINEMENTS OF JENSEN'S INEQUALITY OF MERCER'S TYPE FOR OPERATOR CONVEX FUNCTIONS
}

\author{
A. Matković, J. PeČArić AND I. Perić
}

\begin{abstract}
Refinements of Jensen's inequality for operator convex functions, which are generalizations of Mercer's result, are proved. Obtained results are used to refine monotonicity properties for power means of Mercer's type, and a comparision theorem for quasi-arithmetic means of Mercer's type for operators.
\end{abstract}

Mathematics subject classification (2000): 47A63, 47A64.

Key words and phrases: Jensen's inequality, operator convex functions, monotonicity, power means, quasi-arithmetic means.

\section{REFERENCES}

[1] W. S. Cheung, A. MatKović AND J. PeČARIĆ, A variant of Jessen's Inequality and generalized means, JIPAM, 7(1) (2006), Article 10.

[2] T. FurutA, J. MićIĆ-Hot, J. PeČARIĆ, Y. SEO, Mond-Pečarić Method in Operator Inequalities, Element, Zagreb, 2005.

[3] I. GAVREA, Some considerations on the monotonicity property of power mean, JIPAM, 5(4) (2004), Article 93

[4] F. HANSEN, J. PeČARIĆ AND I. Perić, A generalization of discrete Jensen's operator inequality and it's converses, Hungarian - Croatian mathematical workshop, Debrecen, 2005.

[5] A. MatKović, J. PeČARIĆ AND I. PERIĆ, A variant of Jensen's inequality of Mercer's type for operators with applications, Linear Algebra Appl, 418 (2006), 551-564.

[6] A. MCD. MERCER, A variant of Jensen's inequality, JIPAM, 4(4) (2003), Article 73. 